\title{
The study of English Phonological Errors of Advanced second Language Learners in Pronouncing similarly-spelled Words
}

\author{
Dangin \\ Sanata Dharma University \\ dangin_forphd@yahoo.co.id \\ Nurvita Wijayanti \\ University of Bangka Belitung \\ vita_janejana@yahoo.com \\ \&
}

\begin{abstract}
The phenomenon of phonological error as the common sense in pronouncing the words not only happens among beginners but also among the advanced English learners. The English learners are also active speakers who use English as their second language used such as in a formal situation. They tend to pronounce the same for words that have same spelling as other words in most parts of the words or even thewhole words but of different parts of speech. The present writers' study tries to answer the question on how the English learners' pronunciation is influenced by words with the same spelling. The participants of the study were Indonesian college students who learned English at the advanced level. In order to get the data, they were given word lists that contained a number of words and then asked to pronounce them. These words were suspected as common mistakes pronounced by the advanced learners. For example the word 'determine' is pronounced the same as the word 'mine', the word 'preface' is pronounced as 'face'. In this study, the result reveals that the English learners tend to pronounce the words that refer to other words that contain the same orthography. Orthographically, the words and part of the words have the same spelling but they do not share the same pronunciation. Therefore, this error is commonly found among English learners even among those of the advanced level.
\end{abstract}

Key words: same spelling, phonological error, advanced learners, second language

\section{INTRODUCTION}

English is the language of different spelling and sounds that affect the way its speaker pronounce the words. It is supported that $\mathrm{J}$. Vernick and J. Nesgoda who state that language learners may find difficulties in learning to speak English well because several spelling may be represented by a single sound ( $p$. xi). However, for native speaker, it is quite natural for them to pronounce even the rarely familiar words. They can deliver the pronunciation well without any much effort to adapt with it.

It is quite different with non-English speaker especially Indonesian people who consider English as the foreign language. They do not use English as their formal situation like in school, college and many other formal occasions. Fortunately, referring as a second language user, English has special position in the field of English language studies where learners as it is called advance learners - are supposed to use English as their formal occasion especially in the classroom and other learning activities. As a consequence, they are expected to have more knowledge of English language though of course the frequency of using the language is also limited. Therefore, they do not have much experience in achieving English environment especially, in this focus of paper, the common phonological errors of advanced second language learners in pronouncing the similarly-spelled words.

As an advanced learner, pronunciation is not a big deal to learn since they have already passed the knowledge of basic of it. They mostly can pronounce the words very well without any effort to adapt with it. However, when it comes to the irregularity of spelling-to-sound words, they have to take a challenge to pronounce them.

In this paper, spelling-to-sound words are introduced as the a result of inconsistency of words as it is stated by Chia-Ying Lee in her journal entitled Rethinking of the Regularity and Consistency Effects in Reading. Furthermore, she gives the examples in the words made, jade and ladethatare pronounced the same while the words wave and have are not the same. She explains that there is a consistency effect in the word 
body $-A V E$ and $-A D E$ that the ease of pronouncing a word depends on the relative consistency of the pronunciation of the letter patterns in the words (p. 178).

The paper analyzes the word body that is part of another word. The word body here means the word that is the smallest unit of word that is called phoneme. Therefore, the word body has the meaning as a word. It contains the same spelling information however when it comes as a part of syllables, it is pronounced differently. As an advance second language learner, sometimes it is like common phonological errors that they encounter when pronouncing the same spelling. Thus, there are two research questions to be conducted in this paper; what are the similarly-spelled word lists and affecting words? How does affecting words influence the phonological errors of advanced learners in pronouncing the similarly-spelled words?

This paper takes the topic as the phonological error produced by the advance learners in this case undergraduate students who are the participants. According to Rod Ellis in his book titled Second Language Acquisition, the word error is different with mistake in the way the participants get the knowledge. Errors happen as the result of the limitation of learner's knowledge, while mistakes indicate that the learners who have already known the knowledge but is unable to perform the knowledge what he or she knows (p.17). He also distinguishes and identifies the classification of errors as follows:

Another way might be to try to identify general ways in which the learners' utterances differ from the reconstructed targetlanguage utterances. Such ways include 'omission' (i.e. leaving out an item that is required for an utterance to be considered grammatical), 'missinformation' (i.e. using one grammatical form in place of another grammatical form), and 'misordering' (i.e. putting the word in an utterance in the wrong order) (p.18).

Max Coltheart's and David Plaut's, Mark Seidenberg's theory, says that there are two different ways to represent the knowledge on spelling-to-sound correspondences namely Dual Route Cascade by Coltheart and Parallel Distributed Processing by Plaut. However, both models predict an interaction between word frequency and spelling-to-sound regularity/consistency in word naming.

Coltheart says that spelling-to-sound knowledge can be represented by the grapheme-to-phoneme corresponding (GPC) rules. Furthermore, the words can be defined as regular or irregular depending on whether their pronunciations follow the GPC rules (1993 \& 2001). There are two distinctive routes from print to sound; lexical route and indirect or assembled route. Lexical route allows highly-frequency or irregular spelled words to be 'sounded out' by directly mapping the whole word form to its phonological representation. While indirect route that is for regularly spelled words and pseudowords, in which the individual letter units (graphemes) are translated into corresponding sound units (phonemes) via the GPC rules.

The other ways is based on Plaut's and Seidenberg's theory called Parallel Distributed Processing (PDP) that emphasizes the role of learning and claims that spelling -to-sound knowledge is represented in a distributed approach. Thus, word recognition is an instantiation of a continuous and dynamic learning process that depends on the interaction among the new input, the current state of the system and its previous history. Spelling-to-sound knowledge is represented as weights on connections between units that represent spelling and those that represent sound.

The other affecting factors are the overgeneralization that commonly happens among the learners since the word body has the same spelling. It is in line with W.N Al-Baldawi and A.M Saidat who state overgeneralization is occurred when one overextends one rule to cover instances to which that rule does not apply (p.185).

C. James in P. Heydari's and M.S Bagheri's journal titled Error Analysis: Sources of L2 Learners' Errors says that simplification is also the factor that influences the phonological errors conducted by misusing of words or grammatical rules (1585). From the quotation it is said that the learners try to simplify the rules to be applied in the using 
English as their foreign language, though the learners here are the advanced learners.

\section{METHODOLOGY \\ Participants}

There were 13 males and 17 females advanced English as Foreign Language learners, who were randomly selected from those population who were attendig English department of Sanata Dharma University. John Creswell in his book entitled Education Reseacrh: Planning, Conducting and Evaluating Quantitative and Qualitative Research, random sampling was used to gain data in order to choose to be sampled who will be representative of the population (p.143).

\section{Materials}

The materials consisted of the number of word lists (one single was word followed two words that had similarly-spelled word). These lists of word were chosen in a way that they revealed advanced foreign learners' phonological errors in pronouncing similarly-spelled words.

\section{Procedures}

The research covered two main phases: deciding the word lists and participants. The lists of word were considered through selecting process that was suspected to represent the phonological errors of advanced learners in pronouncing similarlyspelled words. Then the participants were asked to read the suspected words loudly while they were recorded in the silent room therefore to gain the high quality of recording.

\section{DISCUSSION}

As it was stated before, the main purpose of the study was to find out the influence of phonological distribution toward phonological errors conducted by advanced English as Foreign Learners. Table 1.1 reveals the finding of analysis of phonological errors in pronouncing the similarly-spelled words.
Table 1.1. The participants' incorrect pronunciation

\begin{tabular}{|c|c|c|c|c|}
\hline $\begin{array}{c}\text { Word } \\
\text { s }\end{array}$ & $\begin{array}{l}\text { Correct } \\
\text { pronun } \\
\text { ciation }\end{array}$ & $\begin{array}{c}\text { Particip } \\
\text { ants' } \\
\text { pronun } \\
\text { ciation }\end{array}$ & $\begin{array}{c}\text { Affe } \\
\text { cting } \\
\text { word } \\
\text { s } \\
\end{array}$ & $\begin{array}{l}\text { perce } \\
\text { ntage }\end{array}$ \\
\hline $\begin{array}{c}\text { Prefa } \\
\text { ce }\end{array}$ & $\begin{array}{c}\text { /'pref-əs } \\
/\end{array}$ & /prifeis/ & Face & $80 \%$ \\
\hline $\begin{array}{l}\text { Cowa } \\
\text { rdice }\end{array}$ & $\begin{array}{c}\text { /'kavədI } \\
\mathrm{s} /\end{array}$ & $\begin{array}{c}\text { /'kavəd } \\
\text { aIs/ }\end{array}$ & Dice & $70 \%$ \\
\hline $\begin{array}{c}\text { Capri } \\
\text { ce }\end{array}$ & /kə'pri:s/ & $\begin{array}{c}\text { /kə'praI } \\
\mathrm{s} /\end{array}$ & Price & $70 \%$ \\
\hline $\begin{array}{l}\text { Desig } \\
\text { nate }\end{array}$ & $\begin{array}{c}\text { /'dez.Ig. } \\
\text { neit/ }\end{array}$ & $\begin{array}{c}\text { /dI'zaIn } \\
\text { eit/ }\end{array}$ & $\begin{array}{c}\text { Desi } \\
\text { gn }\end{array}$ & $60 \%$ \\
\hline $\begin{array}{c}\text { Surfa } \\
\text { ce }\end{array}$ & /'s3r-fəs/ & /sərfeIs/ & Face & $60 \%$ \\
\hline $\begin{array}{l}\text { Oppo } \\
\text { site }\end{array}$ & $\begin{array}{c}\text { /'ap·ə·zI } \\
\text { t/ }\end{array}$ & $\begin{array}{c}\text { /'ap-əsa } \\
\text { It/ }\end{array}$ & Site & $36 \%$ \\
\hline $\begin{array}{c}\text { Novic } \\
\mathrm{e}\end{array}$ & $\begin{array}{c}\text { /'nav'əs } \\
/\end{array}$ & I'navais & Vice & $30 \%$ \\
\hline
\end{tabular}

The table shows the word lists that were extracted through the original version of the original number of the words. The words in the table were the result of the common sense of advanced English learner in pronouncing the similarly-spelled words. Thus, they were pronounced incorrectly because of the affection of the word body that has similarly-spelled words.

The first word preface showsthe highest frequency - $80 \%$ - the phonological error conducted by the advanced learner. Based on the hypothesis, the advanced learners will pronounce the goal words (preface) incorrectly as above table; it is stated as participants' pronunciation. The result shows that the advanced learners indeed pronounce incorrectly since the affecting word says so. Further, it explains that the word preface is pronounced incorrectly since the affecting word- face has influenced the way the advanced learners pronouncing the targeted word.

The next words;cowardice and caprice are the words that have influenced by the affecting words dice and price respectively. The frequency is under the word preface which means that the participants pronounce incorrectly as the affecting words have the same spelling but it turns out that the pronunciation is not the same.

The words design and face influence the way learners pronounce the words 
designate and surface in less frequency $60 \%$ for each - that means the learners still mostly have errors in pronouncing those words. Finally, opposite and novice are pronounced also in the very least errors by advanced learners since they are quite familiar with those words which are in the percentage of each $36 \%$ and $30 \%$.

\section{Understanding learners' need}

After being recorded, the researchers have clarified the proper pronunciation in order to fix their errors. During the clarification, the researchers have also asked them question "what factors that affect the way their pronounce the word". The following sentences are the answers of some students:

Learner 1: "the word prefaceis familiar for me, then I think it is same with facepronunciation"

Learner 2: "I never check my dictionary because I think it has the same spelling so I pronounce it with the same pronunciation"

From quotation above, it can be drawn that overgeneralization occurs in learner 1 . It indicates that the learner tends to speculate the pronunciation conjecturally without confirming with proper sources such as dictionary, lecturers or even the native speakers. Thus, herein, the learners should be more active in proving the correct pronunciation however they think it is already correct. In another word, they have to be self-corrected learners.

Furthermore, the different case occurred in the second quotation reveals that simplification also happens in the second learner who has admitted that he has never consulted the dictionary to find the truth about the pronunciation. It is because mostly the learners will learn the word that is familiar like the affecting words face, dice, price, design, site, vice in line with preface, cowardice, caprice, designate, surface opposite and novice. In this case, the most important way to overcome the simplification is to be active in consulting the dictionary no matter how complicated it is. When reading the dictionary, avoid to focus only on the meaning but the learners have to pay attention to the phonetic transcriptional aspect.

\section{CONCLUSION}

The study undertook to investigate the phonological errors of advanced foreign language learners from articulatory phonetics. There were thirty participants; 13 males and 17 females were randomly selected from a number of population. The data were collected through recorded data that consisted of word lists; both affecting words and similarly-spelled words along with learners' voice recording. This research also did not involve cultural and social background of the participant as the consideration in the sampling process.

The data were collected through recording the learners' pronunciation. Then, the collected data were analyzed by checking for their phonological errors comparing with the correct phonetic transcription. As it was seen in table 1.1, the learners tended to pronounce the list of words that consisted of similarly-spelled words with another affecting word such as preface pronounced as face, cowardice pronounced as dice, caprice - price, designate- design, surface - face, oppositesite and novice - vice. It seemed common sense for the learners to pronounce the similarly-spelled words affecting words.

Therefore, the advanced learners should be able to be aware in their pronunciation especially in similarly-spelled words. They should avoid some cases; overgeneralization, simplification and paying attention of the inconsistency in English phonology. 


\section{REFERENCES}

Al-Baldawi, Nazar, W. \& Saidat A. M. (2011). "LINGUISTIC OVERGENERALIZATION: A CASE STUDY." International Journal of Academic Research in Business and Social Sciences 1: 184-93. HRMARS. Web. http://www.hrmars.com/admin/pics/103.pdf

Coltheart M., Kathleen R., Conrad P., Robyn L., \& Johannes Z. (2015). "DRC: A Dual Route Cascaded Model Of Visual Word Recognition And Reading Aloud." Psychological Review: 204-56. Web. 12 Jan. <http://psiexp.ss.uci.edu/research/teachingP140C/Papers/Coltheart_etal_2001.pdf

Creswell, J. W. (2012). Educational Research: Planning, Conducting, and Evaluating Quantitative and Qualitative Research. 4th ed. Boston: Pearson. Print.

Ellis, R. (1997). Second Language Acquisition. 2nd ed. Oxford: Oxford UP.

Heydari, P. \& Mohammad S. B. (2015). "Error Analysis: Sources of L2 Learners' Errors." Theory and Practice in Language Studies (2012). Web. 21 Jan. $<$ http://ojs.academypublisher.com/index.php/tpls/article/download/tpls020815831589/51 $\underline{34}>$.

Lee, C. Y. (2008). "Rethinking of the Regularity and Consistency Effects in Reading." Language and Linguistics.9.1 177-186.

Plaut,D. C. (1996). Relearning after damage in connectionist networks: toward a theory of rehabilitation. Brain and Language. 52.1:25-82.

Seidenberg, M. S. (1998) The time course of phonological code activation in two writing systems. Cognition 19.1:1-30.

Vernick, J., \& Nesgoda, J. (1980). American English sounds and spellings for beginning ESL students. Pittsburgh: University of Pittsburgh Press. 